\title{
EXCAVATION REPORT FOR THE BOMBORO SITE: A CHERT QUARRY SITE IN THE BOMBORO VALLEY, MAROS REGENCY, SOUTH SULAWESI
}

\section{Laporan Ekskavasi terhadap Situs Bomboro: Situs Tambang Rijang di Lembah Bomboro, Kabupaten Maros, Sulawesi Selatan}

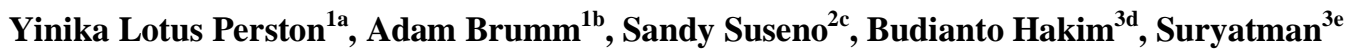 \\ ${ }^{1}$ Australian Research Centre for Human Evolution at Griffith University, School of Environment and Science, \\ N78, 170 Kessels Road, Nathan Campus, Brisbane, Qld, Australia. \\ ${ }^{2}$ Jurusan Arkeologi, Fakultas Ilmu Budaya, Universitas Halu Oleo, Sulawesi Tenggara, Indonesia. \\ ${ }^{3}$ Balai Arkeologi Provinsi Sulawesi Selatan, Jl. Pajjaiyang No. 13 Sudiang Raya, Sulawesi Selatan, Indonesia

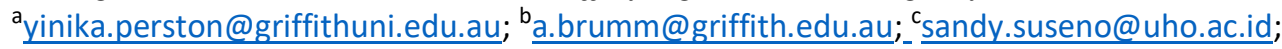 \\ dbudianto.hakim@kemdikbud.go.id; 'suryatman.arkeologi@gmail.com
}

Received: 28/02/2020; revision: 30/12-03/06/2021; accepted: 07/06/2021

Published online: 25/06/2021

\begin{abstract}
Abstrak
Kawasan karst Maros-Pangkep berisi banyak situs arkeologi Holosen dan Pleistosen Akhir, banyak diantaranya berisi himpunan artefak yang didominasi oleh artefak rijang. Namun demikian, belum ada informasi mengenai sumber untuk bahan baku yang telah teridentifikasi. Sementara batuan dasar kapur yang melimpah kadang-kadang berisi kantong dan lapisan nodul rijang, singkapan ini menunjukkan sedikit bukti untuk eksploitasi atau tambangan prasejarah, dan kecil kemungkinan rijang diperoleh dari anak sungai atau sungai. Situs Bomboro dipilih untuk penggalian karena permukaan tanahnya yang kaya dengan artefak batu, termasuk serpihan, batu inti dan tatal. Rijangnya mungkin telah ditambang dari nodul yang keluar melalui batu gamping lokal di Lembah Bomboro. Sampai sekarang, situs ini merupakan tambang batu kuno pertama yang diidentifikasi di wilayah tersebut. Sementara tambang terbuka tidak ada duanya, mungkin berfungsi sebagai sumber rijang selama periode Toalean, sekitar 2-8 ribu tahun yang lalu.
\end{abstract}

Kata Kunci: Sulawesi Selatan; artefak rijang; situs terbuka.

\begin{abstract}
The Maros-Pangkep region contains numerous archaeological sites dating from the Holocene and LatePleistocene, many of which contain artefact assemblages dominated by flaked chert artefacts. However, no sources for this raw material have yet been identified. While the abundant limestone bedrock contains occasional pockets and seams of chert nodules, these outcrops show little evidence for prehistoric exploitation or quarrying, and it is unlikely the chert was acquired from streambeds. The Bomboro site was selected for excavation as the ground surface is rich in chert stone artefacts including flakes, cores, and debris. This chert was likely quarried from the local nodules outcropping from the surrounding limestone bedrock in the Bomboro Valley, and this report describes the excavation of the first ancient stone quarry site to be identified in the region. While the open quarry was undateable, it may have served as a chert source during the Toalean period, around 2-8 thousand years ago.
\end{abstract}

Keywords: South Sulawesi; chert artefacts; open site.

\section{INTRODUCTION}

South Sulawesi (i.e., the southwestern penninsula of Sulawesi) contains dozens of published sites with preNeolithic archaeological deposits, and countless more remain undiscovered or have only been recorded in internal reports. These sites date to between approximately 2 thousand years ago (kya) as far back to over 
194 kya at Talepu in the Cabenge regency (van den Bergh et al., 2016). Cultural remains at every one of these sites are dominated by chert (sometimes described as 'silicified limestone'), artefacts, however very few potential archaeological sources for this stone have been identified. In 2017, a new open site was identified in the Bomboro valley of Maros regency that appeared to be a chert nodule reduction site. Excavations were conducted within this area to investigate the possibility that this location was an archaeological quarry site and that it may have been a raw material source for tool makers at the nearby Late Pleistocene site of Leang Bulu Bettue (Brumm et al., 2017) or at the numerous mid-Holocene 'Toalean' cave assemblages in the region (e.g. Glover, 1976; Hakim, 2017; Hakim et al., 2009; Suryatman et al., 2019).

\section{SITE DESCRIPTION}

\section{Location and Current Use}

The Bomboro valley lies approximately 2.5 kilometres north of the Taman Prasejarah Leang-Leang in the Maros-Pangkep limestone karst region of South Sulawesi, $17.8 \mathrm{~km}$ north of the capital Makassar (Figure 1). The name of the Bomboro site has here been used to refer to a large open chert quarry within the valley, just to the north of a collection of houses. Today the valley is mined at a small scale for limestone, using small fires and handwielded hammers to break the stone into large cobbles which are then carried out by truck. Two roads lead into the valley from the southern end. Farther into the valley and beyond the end of the access road lies a small Islamic cemetery. The valley beyond this cemetery is primarily used for teak tree plantations, and is covered by thick but

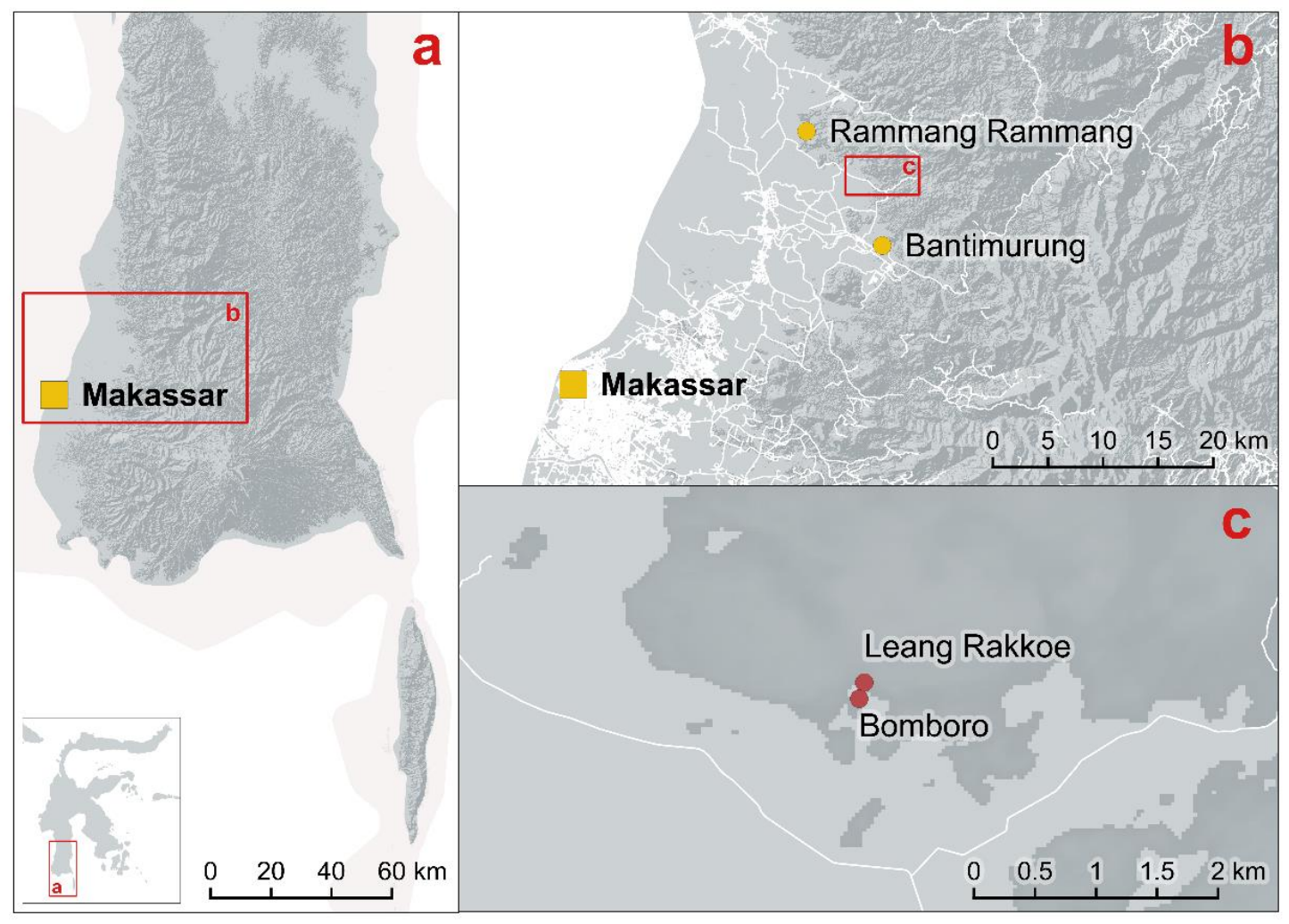

Figure 1. Location of Leang Rakkoe and the Bomboro excavation within the Bomboro valley of the Maros regency of South Sulawesi, showing elevated areas in darker green. Coordinates for the Bomboro excavation: $\mathrm{S} 04^{\circ} 57.652^{\prime}$, E $119^{\circ} 40.143^{\prime}$. Approx. 85m above sea level. (Source: Kim Newman, 2020) 
disturbed vegetation, severely restricting surface visibility. The whole area abuts the Bantimurung Bulusaraung National Park.

It is within this teak plantation that surface evidence for ancient chert quarrying was first identified. The surrounding limestone bedrock and cliffs contain seams of natural chert nodules which have been systematically flaked, leaving an extensive lithic scatter (Figure 2). Further up the valley, and abutting the cliff wall, the shallow rockshelter of Leang Rakkoe contains artefacts and faunal remains attributed to the Toalean phase of occupation, which dates to ca. 2-8 kya (e.g. Suryatman et al., 2019) as well as a series of
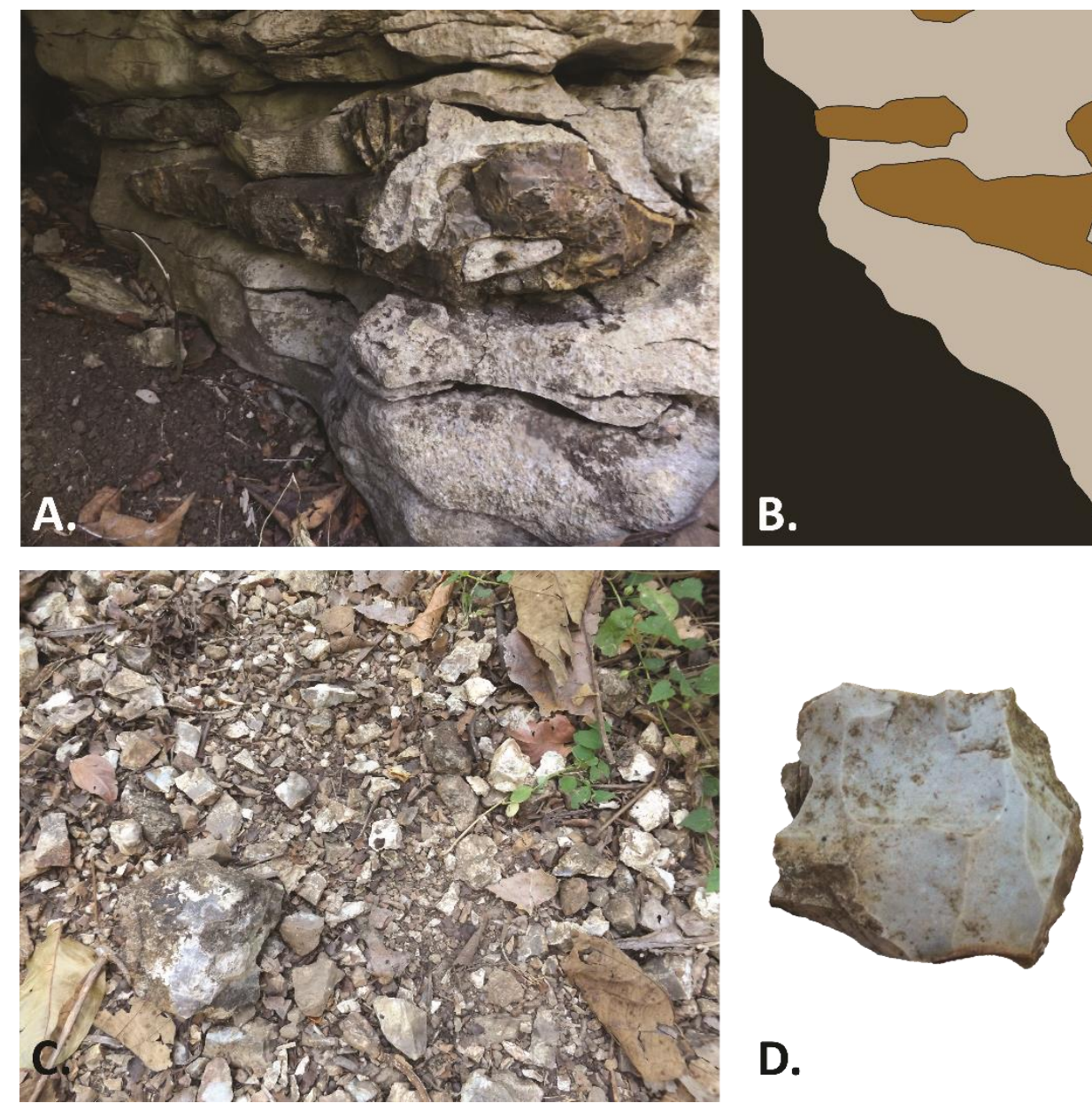

Figure 2. Signs of archaeological quarrying in the Bomboro valley. A \& B Chert nodules embedded in limestone bedrock. C Chert shatter across valley floor, mostly natural. D Surface finds of a core and a flake

(Source: Yinika Perston, 2017)

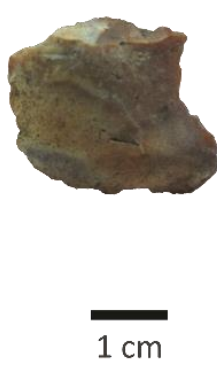

linear artificial grooves in the rock face above (Perston et al., 2020).

\section{Context and Extent}

The chert quarry site was first identified by $\mathrm{AB}$ and $\mathrm{BH}$ in mid-2017 during a survey of local cave sites within the Bomboro valley. It was more thoroughly surveyed and mapped by a small team in September of the same year. The survey confirmed that the presence of naturally occurring chert nodules, dense scatters of chert shatter, and chert artefacts including cores and flakes.

The quarry site lies within a long, wide valley that runs roughly north to south. The eastern and western slopes are covered

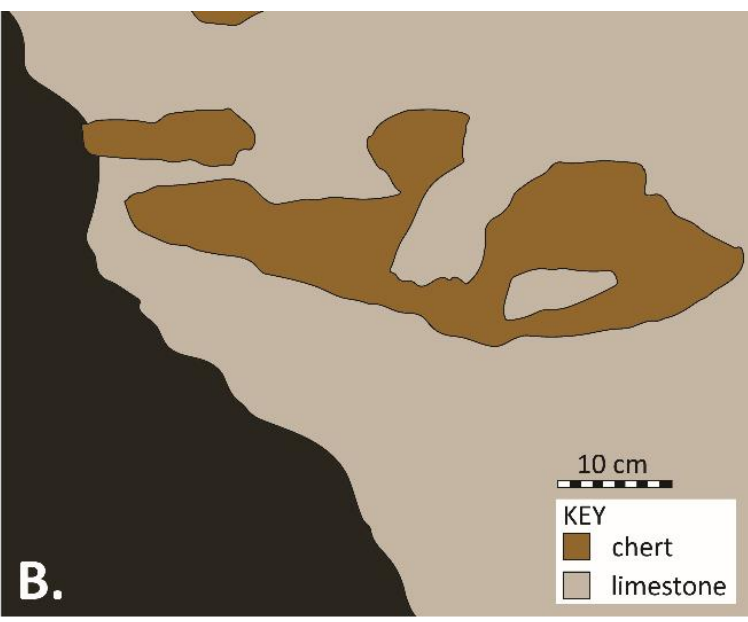

$1 \mathrm{~cm}$ 
in large limestone boulders and thick undergrowth. No artefacts were observed on these slopes, although the chert nodules continued to occur for quite some distance. The centre of the valley is quite flat, and a thick scatter of chert artefacts and shatter can be found on all exposed ground surfaces. To the north, this scatter appears to end abruptly at a point where the valley floor becomes dominated by steep hills of sharp, crumbling limestone. At this point the elevation increased steeply and the native vegetation also becomes less disturbed with no agriculture, an increase in large native trees, and a decrease in the low, tangled undergrowth. Although the field survey extended for some distance into this northern area no artefacts and very few chert cobbles were encountered. The southern extent of the quarry zone was more difficult to define as this area has been highly disturbed in recent years by local limestone mining, erosion, and constant truck activity, but artefacts can still be found amongst the limestone rule and within the small creek bed that winds down the valley. The entire site, defined by the visible presence of stone artefacts scattered over the surface, appears to extend approximately $255 \mathrm{~m}$ long and $25 \mathrm{~m}$ wide.

\section{Raw Material Source}

The chert at the Bomboro site occurs as nodules embedded within the limestone and as eroded fragments on the valley floor. Nodules appear to occur in multiple horizontal seams, ranging in size from small pebbles up to lens-like nodules measuring up to around one to two metres across. Many nodules are still embedded in the limestone, while others have eroded out. Most of the material itself is of fairly poor quality as the cobbles are full of flaws and shatter when struck without displaying the features of deliberate flaking (pers. obs., YLP). However, the shattered pieces are quite sharp, and could potentially have been used as tools in their own right. All accessible nodules still embedded in the bedrock appeared to have been reduced (flaked) in situ until flush with the rock face.

\section{Purpose of Excavation}

The site is situated within walking distance (approximately $4 \mathrm{~km}$ ) of the Pleistocene site of Leang Bulu Bettue. This large cave site contains deep and rich occupation deposits dating from at least 40 kya that includes faunal remains, ochre pieces, bone ornaments, and thousands of stone artefacts (Brumm et al., 2017; Brumm et al., 2020). Approximately $91.84 \%$ of the artefacts at Leang Bulu Bettue are chert or silicified limestone, and from the cortex it appears the stone was primarily acquired directly from seams and nodules (Brumm et al., 2020). However, the source of this material is currently unknown. Bomboro was investigated as a potential source for this chert raw material.

While a large amount of chert is visible in areas of the Bomboro valley floor not covered by undergrowth, much of this surface material is shatter that cannot be attributed to deliberate flaking - i.e. the stone is comprised of thick angular fragments that lack a point of percussion, any ventral or dorsal features, negative flake scars, or any other definitive features of deliberate flintknapping. However, the presence of at least one core on the ground surface and countless small flakes, as well as the abundant lithic artefacts turned up by the excavation of graves in the cemetery, indicated that the assemblage continues well below the surface. For this reason, a small test pit was excavated in a flat part of the creek terrace to assess the subsurface artefact distribution and better understand the site's role as a quarry.

\section{METHOD}

In July 2018 a 1 metre by 1 metre square test pit was excavated in a relatively open, flat patch of the apparent quarry close to the northern extent of the surface scatter (Figure 3). Stone artefacts and fragments of 


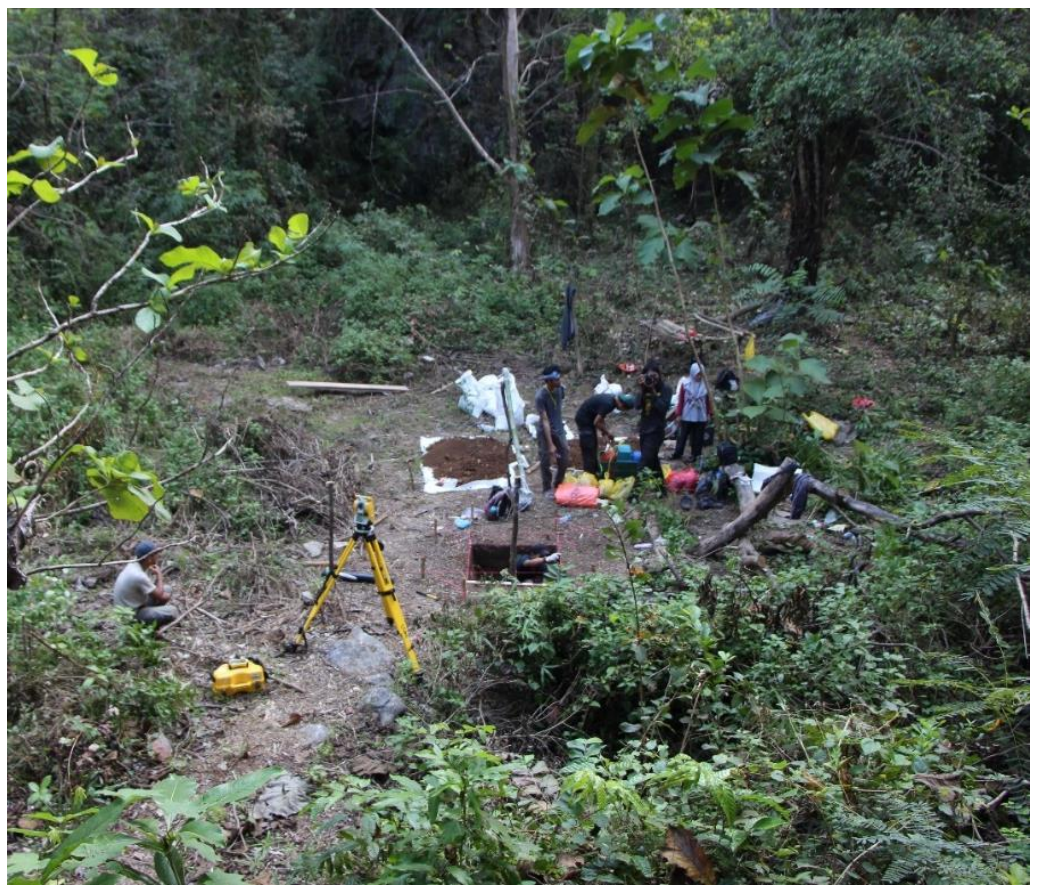

Figure 3. Overview of the Bomboro excavation site showing context and excavation (Source: Burhan, 2018)

chert were visible on the ground. The excavation was conducted in $10 \mathrm{~cm}$ spits, as little stratigraphy was visible (Research Team, 2018, unpublished). Excavation was done using hand-held trowels and brushes. All sediment was dry sieved through $3 \mathrm{~mm}$ and a $1 \mathrm{~mm}$ sieves on site, and the sieved sediments used as backfill at the end of the excavation.

A full analysis of the finds recovered from the Bomboro excavation has not yet been conducted, however basic information was collected. Stone artefacts were sorted from non-cultural fragments (after Holdaway \& Stern, 2004), weights were recorded, and observations were made on the technology.

\section{RESULTS}

\section{Deposits and Stratigraphy}

The soil at Bomboro was composed of moist compact clayey soil, dense with small chert stones and small roots. A tree root extended through the east end of the excavation. Three stratigraphic layers were identified. The uppermost, Layer 1, consisted of dark brown sandy clay below the humus topsoil, and was dense in artefacts and unmodified stone pieces down to approximately $30 \mathrm{~cm}$ below the surface. Below this layer the soil was lighter yellowing clay, Layer 2, and artefact finds declined though were still present (see below). There was no distinct change to Layer 3, and excavation stopped when artefacts declined dramatically at $60 \mathrm{~cm}$ depth (Figure 4). No samples were encountered for dating, and there was no organic preservation. Cultural material consisted entirely of stone artefacts.

\section{Stone Artefacts}

The Bomboro test pit contained 4.6 $\mathrm{kg}$ of stone artefacts, or 5,059 artefacts over the size of $1 \mathrm{~mm}$. The unmodified stone was not weighed or counted. The lithic artefacts were dominated by larger pieces, as 4,203 $(83 \%)$ were over $3 \mathrm{~mm}$. Stone artefacts were concentrated in the uppermost $20 \mathrm{~cm}$ of deposits (Layer 1), though still occurred at a rate of 95 artefacts in the lowermost spit. A spike in the ratio of stone cores occurred in Spit 5, creating a bimodal distribution in artefact weights (Figure 5). 

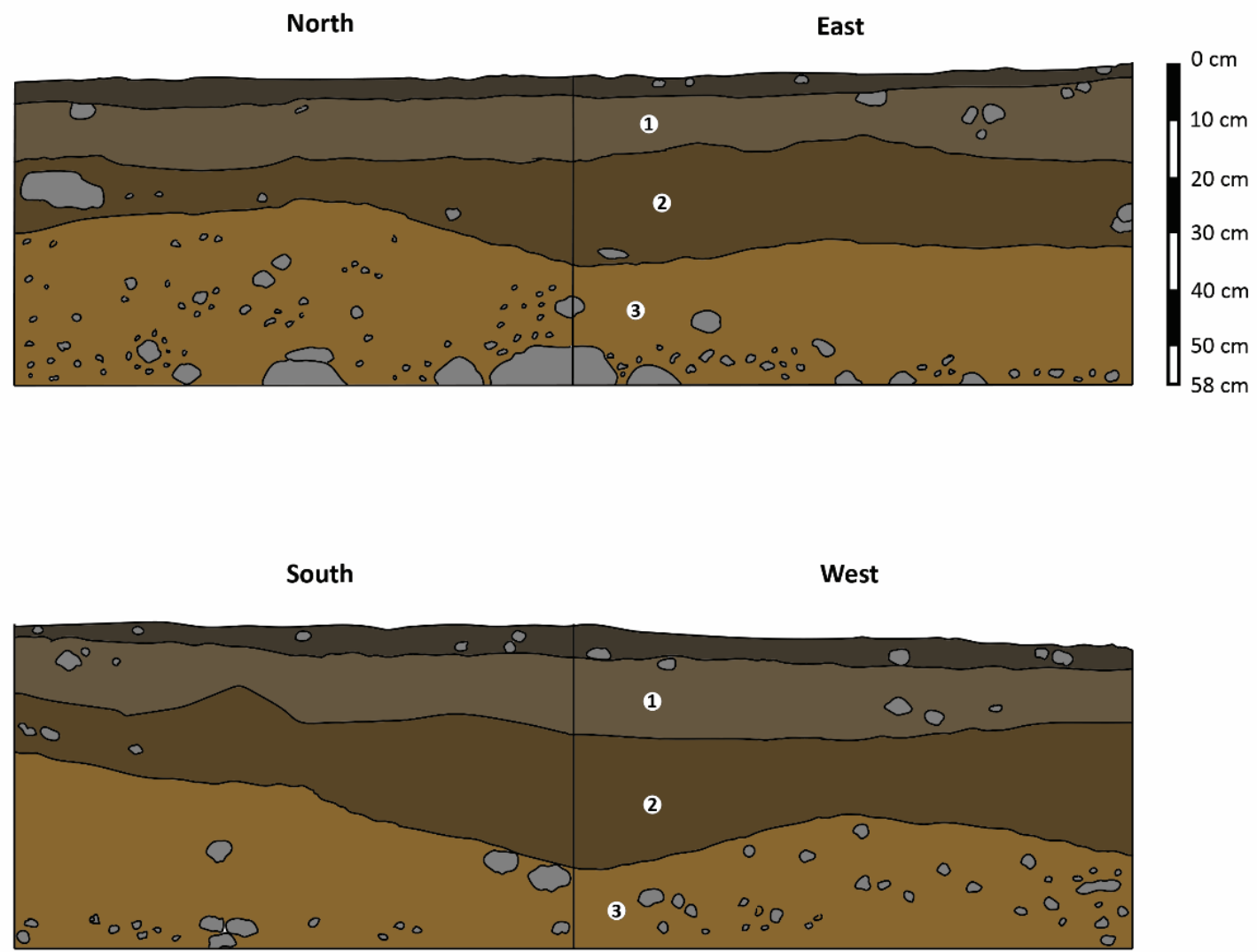

Figure 4. Stratigraphic section diagram of the Bomboro excavation. (Source: Yinika L. Perston, 2020, adapted from diagram by Khaeril Akram, 2018)

A comprehensive analysis has not yet been carried out of the excavated Bomboro lithic assemblage, but some general observations on the technology have been made. All artefacts were made from chert, and heatinduced 'potlids' and fracturing was common, indicating the artefacts have been exposed to quick and/or intense fires. However, there is no evidence for deliberate heat treatment, such as differential gloss on flakes. Flakes and flake scar attributes indicate that reduction was done by hard hammer percussion. The unmodified chert occurs naturally in angular, blocky piece with planes of natural flaws, and perhaps because of this characteristic the cores were generally irregular and chunky, with areas of quality chert opportunistically targeted as it occurred among areas of flaws and crystal seams. The resulting flakes were generally small and nondescript, often fairly thin and with no signs of modification such as retouch. The Bomboro artefacts did not show any significant signs of weathering despite their exposed location.

The artefacts recovered from the Bomboro excavation did not include any artefacts that could provide an approximate age estimate for the chert quarry. Classic Toalean assemblages tend to include diagnostic artefact types including backed microliths and Maros points (Bellwood, 2007, pp. 193-196; Mulvaney \& Soejono, 1970, p. 171), while the Late Pleistocene assemblage at Leang Bulu Bettue includes frequent bipolar reduction and the occasional reduction of large limestone blanks (Brumm et al., 2017). In contrast, the Bomboro assemblage only consisted of unmodified chert flakes and non-diagnostic cores. 

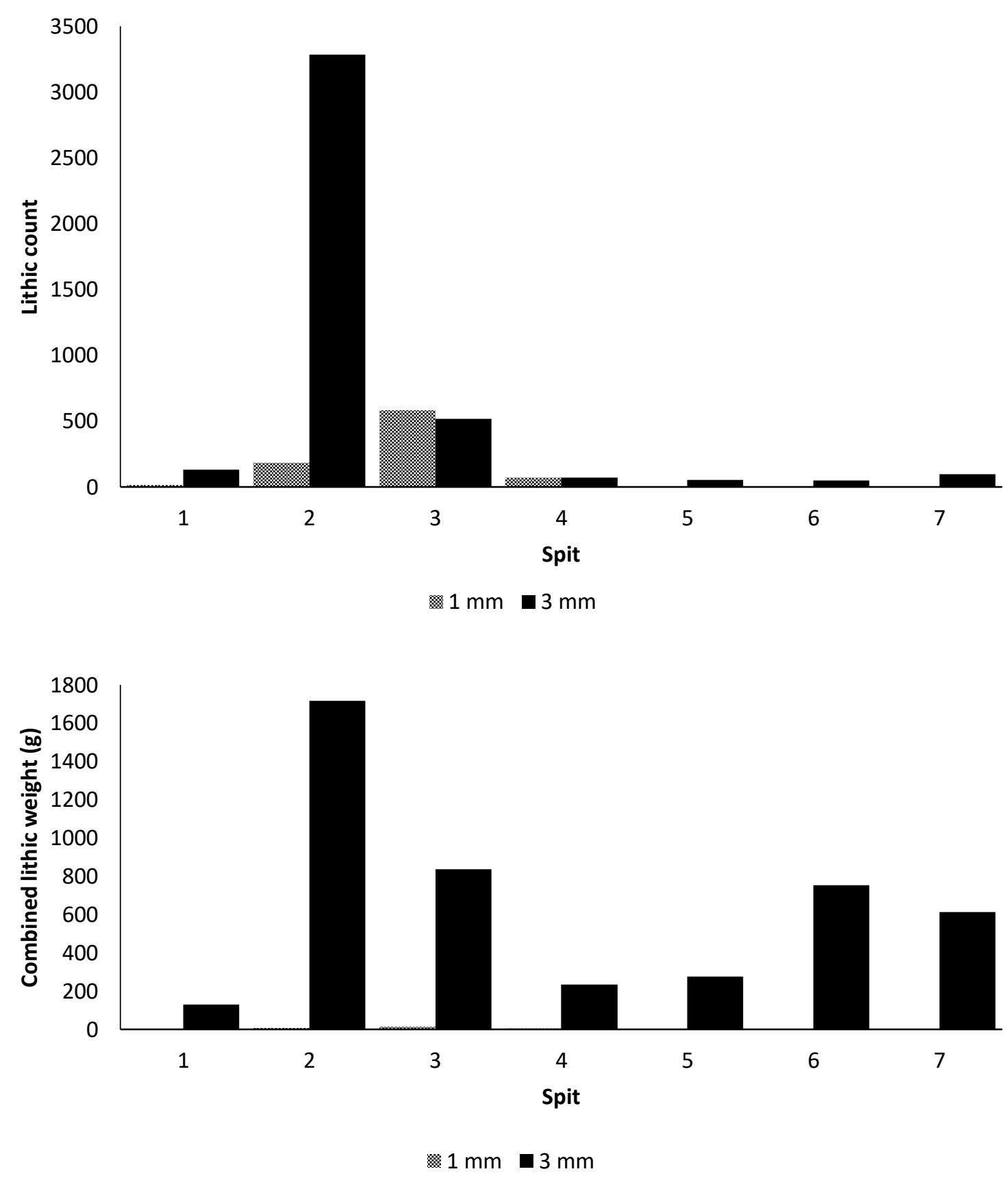

Figure 5. Lithic counts and weights in the excavated Bomboro deposits (Source: Yinika L. Perston, 2020)

\section{CONCLUSION}

Excavations and surveys at Bomboro confirmed that the site is an extensive and intensively used prehistoric chert quarry site. Chert was quarried for stone artefact production, creating an extensive knapping floor across the valley.
The Bomboro lithic scatter is heavily deflated. The density of chert debris, debitage, and flaked artefacts that was visible on the surface dropped off dramatically at approximately $30 \mathrm{~cm}$, suggesting heavy deflation to this depth, and the associated soil change at this point may be the interface between soil horizons. Deflation may have occurred from heavy 
seasonal rains, common in this tropical region, perhaps exacerbated by flooding from the nearby stream. A number of forest fires have likely occurred, as the heat damage is critical and extensive. While fire has been used to procure stone from some stone quarries in Australia and elsewhere (e.g. Binford \& O'Connell, 1984; Florek, 1989), this does not appear to be the case at Bomboro where embedded chert nodules only show evidence of reduction through hard hammer percussion.

Excavation did not clarify the chronology of exploitation of the site as a stone source, nor document a clear association with the stone artefacts at the Late Pleistocene cave site of Leang Bulu Bettue. Unlike the Leang Bulu Bettue stone tools, the stone artefacts from the Bomboro excavation are not heavily weathered, so it is possible to argue that most of the stone artefacts may be Holocene in age; however, in the absence of any distinctive tool types it cannot be definitively placed into any period. Artefacts at Leang Bulu Bettue do not show the natural fracture planes or planar flaws common in the Bomboro chert (Brumm et al., 2017; pers. obs., YLP), and while this finding may reflect a selection bias by the Leang Bulu Bettue tool-users we suggest that these Pleistocene knappers may have procured most or all of their stone from elsewhere. Many of the chert pieces at Bomboro would nonetheless be sharp and functional, and the considerable volume and extent of the site shows that it was an important stone source at some point in prehistory.

During eight decades of archaeological research in the limestone karsts of the Maros and Pangkep regencies, only one other potential chert source has been described from this vicinity. Chert nodules were reported in the Pattunuang Asue River in front of Leang Karassak, on the Maros-Camba Road by Glover (1978, pp. 68-69). In 2019, our team surveyed this river bed and found thick outcrops of chert nodules eroding from the limestone riverbed exposed at the foot of the village of Pattunuang Asue (a name that translates to 'place of burning dogs'), at coordinates

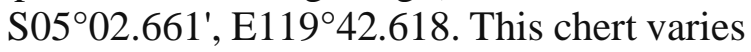
in colour and quality but does not appear to have flaws and seams as seen in the raw material at Bomboro. It is therefore possible that the outcrops at Pattunuang Asue may have been used as a stone source for the stone artefacts of Leang Bulu Bettue and neighbouring sites such as Leang Karassak. Long-distance procurement strategies seem unlikely, due to the sheer volume of material, however this has not been explored in greater detail.

In conclusion, a preliminary excavation at the Bomboro open lithic site confirmed that the valley contains an extensive but weathered and deflated prehistoric chert quarry, but the age and quarrying activities remain unclear. The high density of stone artefacts demonstrated how heavily utilised this source was, as does the considerable expanse of the scatter when surveyed. Further work at this site may yield important insights into the landscape-scale stone procurement strategies employed by past people in the Maros-Pangkep region.

\section{Acknowledgements}

Our work at Bomboro was supported an Australian Research Council (ARC) Future Fellowship awarded to Adam Brumm (FT160100119), along with generous financial backing from Griffith University, Australia. The Maros-Pangkep Research Project is authorised by the State Ministry of Research and Technology (RISTEK), and is conducted in collaboration with counterpart institution Pusat Penelitian Arkeologi Nasional (Puslit Arkenas), Jakarta, Indonesia. Other key participating organisations in Indonesia include Balai Arkeologi Sulawesi Selatan (Balar Sulsel, Makassar), Balai Pelestarian Cagar Budaya (BPCB Makassar), Departemen Arkeologi Fakultas Ilmu Budaya at Universitas 
Hasanuddin (Makassar), and Jurusan Arkeologi Fakultas Ilmu Budaya of Universitas Halu Oleo (Kendari). We also thank the Maros and Pangkajene Kepulauan Regional governments.

The Bomboro chert quarry was first identified as such by $\mathrm{AB}$ and $\mathrm{BH}$, on land owned by the family of local resident Pak Sinar. A preliminary survey of the valley was conducted by YLP, Igo Hasan Lapeka, and Annisa Senja Rucita in 2017. The Bomboro excavation was led by Sandy Suseno, assisted by Adrianus Dipo Ramelan,
Sarsina 'Sina' Meyni Usman, Sofyan 'Ian' Setia Budi, Khaeril 'Heri' Akram and several BPCB staff. Finds were curated by Hasliana and Hikma and are stored at the Balar Sulsel storehouse. Artefact analysis was conducted by YLP. Thanks to Mark W. Moore, Michelle Langley, Kim Newman, and Basran for feedback on this report, and to Putu Bagus Mahardika for assistance with translations.

\section{REFERENCES}

Bellwood, P. (2007). Prehistory of the Indo-Malaysian Archipelago (Revised Edition) (3rd ed.). ANU E Press. https://doi.org/http://doi.org/10.22459/PIMA.03.2007

Binford, L. R., \& O'Connell, J. F. (1984). An Alyawara day: The stone quarry. Journal of Anthropological Research, 40(3), 406-432. https://doi.org/10.1086/jar.40.3.3629763

Brumm, A., Langley, M. C., Hakim, B., Perston, Y. L., Suryatman, Oktaviana, A. A., Burhan, B., \& Moore, M. W. (2020). Scratching the surface: Engraved cortex as portable art in Pleistocene Sulawesi. Journal of Archaeological Method and Theory, 27 (3), 1-29.

Brumm, A., Langley, M. C., Moore, M. W., Hakim, B., Ramli, M., Sumantri, I., Burham, B., Saiful, A. M., Siagian, L., Suryatman, Sardi, R., Jusdi, A., Abdullah, Mubarak, A. P., Hasliana, Hasrianti, Oktaviana, A. A., Adhityatama, S., van den Bergh, G. D., Aubert, M., Zhao, J.-x., Huntley, J., Li, B., Roberts, R. G., Saptomo, E. W., Perston, Y., \& Grun, R. (2017). Early human symbolic behavior in the Late Pleistocene of Wallacea. PNAS, 114(16), 4105-4110.

Florek, S. (1989). Fire in the Quarry. Australian Archaeology, 29, 22-27. http://www.jstor.org/stable/40286959

Glover, I. C. (1976). Ulu Leang cave, Maros: a preliminary sequence of post-Pleistocene cultural development in South Sulawesi. Archipel-etudes Interdisciplinaires Sur Le Monde Insulindien, 11, 113-154.

Glover, I. C. (1978). Survey and excavation in the Maros district, South Sulawesi, Indonesia. Bulletin of the Indo-Pacific Prehistory Association, 1, 60-102.

Hakim, B. (2017). Interpretasi awal temuan gigi manusia di situs Bala Metti, Bone dan situs Leang Jarie, Maros, Sulawesi Selatan. Walennae, 15, 19-30.

Hakim, B., Nur, M., \& Rustam. (2009). The sites of Gua Pasaung (Rammang-Rammang) and Mallawa: indicators of cultural contact between the Toalean and Neolithic complexes in South Sulawesi. Bulletin of the Indo-Pacific Prehistory Association, 29, 45-52. 
Holdaway, S., \& Stern, N. (2004). A Record in Stone: The Study of Australia's Flaked Stone Artefacts. Aboriginal Studies Press.

Mulvaney, D. J., \& Soejono, R. P. (1970). The Australian-Indonesian Archaeological Expedition to Sulawesi. Asian Perspectives, 13, 163-177.

Perston, Y. L., Sumantri, I., Hakim, B., Oktavia, A. A., \& Brumm, A. (2020). Excavation report for Leang Rakkoe: A new Toalean site with engraved art in the Bomboro Valley, Maros Regency, South Sulawesi. Walennae, 18(2). https://doi.org/10.24832/wln.v18i1.427 . 5164

Research Team. (2018). Unpublished Research Report for the Maros-Pangkep Karst area 2018. Laporan Penelitian Wilayah Karast Maros-Pangkep, Unpub.

Suryatman, Hakim, B., Mahmud, M. I., Fakhri, Burhan, B., Oktaviana, A. A., Saiful, A. M., \& Syahdar, F. A. (2019). Artefak Batu Preneolitik Situs Leang Jarie: bukti teknologi Maros point tertua di kawasan budaya Toalean, Sulawesi Selatan. Amerta Jurnal Penelitian dan Perkembangan Arkeologi, 37(1), 17. https://doi.org/10.24832/amt.v37i1.1-17

van den Bergh, G. D., Li, B., Brumm, A., Grun, R., Yurnaldi, D., \& Moore, M. W. (2016). Earliest hominin occupation of Sulawesi, Indonesia. Nature, 529, 208-211. 